\title{
Brief Review of Coronavirus for Healthcare Professionals February 10, 2020
}

\author{
Richard A. Robbins, MD' \\ Stephen A. Klotz, MD²
}

${ }^{1}$ Phoenix Pulmonary and Critical Care Research and Education Foundation, Gilbert, AZ USA

2Division of Infectious Diseases, Department of Internal Medicine, University of Arizona, Tucson, AZ USA

The epidemic of coronavirus (2019-nCoV) near Wuhan City and the surrounding Hubei Province in China has received extensive news coverage. Some have predicted the virus will cause a worldwide pandemic (1). The CDC has an extensive website discussing over numerous pages whom to suspect, how to diagnose and how to treat 2019-nCoV. 2019-nCoV represents the most recent of the severe coronaviral infections. Severe acute respiratory syndrome (SARS) and Middle East respiratory syndrome (MERS) are also caused by coronaviruses that have jumped from animals to humans like 2019-nCoV. It should be remembered that there are only 12 confirmed cases of $2019-n C o V$ in the US and the mortality rate appears to be only about $3 \%$ which is lower than SARS or MERS $(2,3)$. This could be offset by a greater infectiousness of 2019$\mathrm{nCoV}$ resulting in more aggregate infectious, and hence, deaths.

Anyone with a fever who has recently visited the epidemic area in China or been exposed to someone with known 2019-nCoV should be quarantined (2). The only reliable symptom has been fever (98\%) (4). Cough (76\%), myalgia/fatigue (44\%), sputum production $(28 \%)$, headache $(8 \%)$, hemoptysis $(5 \%)$, and diarrhea $(3 \%)$ were much less common. The clinical course was characterized by the development of dyspnea in $55 \%$ of patients and lymphopenia in $66 \%$.

Persons suspected of 2019-nCoV should be quarantined and reported to their local state health departments. The incubation period appears about 2-14 days and is spread by person-to-person transmission based on the previous MERS epidemic (2). There is no need to wear masks in the US where the incidence is low and they are likely ineffective (2).

Diagnosis is made real-time reverse transcription polymerase chain reaction ( $r R T-P C R)$ assay. This was only available from the CDC but very recently the CDC has made kits available to state health departments (2).

At present the treatment for $2019-\mathrm{nCoV}$ is supportive in appropriate respiratory isolation to protect healthcare workers. A randomized, controlled trial of Gilead's antiviral drug remdesivir used to treat Ebola is currently underway in China in hopes that it will be an effective treatment for 2019-nCoV (5). 
Please be aware that this information is current as of February 10, 2020. It is likely to change.

\section{References}

1. McNeil DG Jr. Wuhan coronavirus looks increasingly like a pandemic, experts say. New York Times. February 2, 2020. Available at: https://www.nytimes.com/2020/02/02/health/coronavirus-pandemic-china.html (accessed 2/10/20).

2. Centers for Disease Control. 2019 Novel Coronavirus (2019-nCoV) in the U.S.

February 10, 2020. Available at: https://www.cdc.gov/coronavirus/2019-ncov/casesin-us.html (accessed 2/10/20).

3. Worldometer. Novel coronavirus (2019-nCoV) mortality rate. Available at: https://www.worldometers.info/coronavirus/coronavirus-death-rate/ (accessed 2/10/20).

4. Huang C, Wang Y, Li X, et al. Clinical features of patients infected with 2019 novel coronavirus in Wuhan, China. Lancet. 2020 Jan 24. pii: S0140-6736(20)30183-5. [Epub ahead of print] [CrossRef] [PubMed]

5. Wetsman N. An experimental antiviral medication might help fight the new coronavirus. The Verge. Feb 4, 2020. Available at:

https://www.theverge.com/2020/2/4/21122327/coronavirus-experimental-medicationtreatment-wuhan-china-gilead-hiv (accessed 2/10/20). 